\title{
TRADISI PERANG TEMBUNG SEBAGAI AKULTURASI BUDAYA PADA MASYARAKAT DESA SEREWE KECAMATAN PRAYA TENGAH KABUPATEN LOMBOK TENGAH
}

\author{
Sipa Sasmanda' ${ }^{1}$ Anwar ${ }^{2}$ \\ ${ }^{1,2}$ Pendidikan Sejarah, Universitas Muhammadiyah Mataram, sipasasmanda@yahoo.com \\ ${ }^{2}$ Pendidikan Sejarah, Universitas Muhammadiyah Mataram
}

\section{INFO ARTIKEL}

RiwayatArtikel:

Diterima: 03-04-2017

Disetujui: 04-06-2017

\section{Kata Kunci:}

1. Tradisi Perang Tembung

2. Akulturasi

\section{A. LATAR BELAKANG}

Dalam hal budaya ataupun tradisi yang dimiliki, Pulau Lombok tidak kalah kayanya dengan daerah lain di Nusantara. Itu terbukti dari demikian banyaknya bentuk tradisi dan situs-situs kebudayaan yang ada di pulau Lombok. Varian-varian bentuk budaya yang dimaksud diantaranya seperti tradisi Bau Nyale, Ngurisang, Besunat, Pedak Awu/Api, Meriri KuburInggas Begawe, Selametan Segare, Bekayak ketika Matak, Perang Tembung, perang topat, Tradisi Ngalu Aik, dan masih banyak lagi yang lainnya di luar sepengetahuan penulis. Pada dasarnya semua itu memiliki nilai-nilai filosofis tersendiri berdasarkan kearifan lokal masyarakat dimana kebudayaan itu tumbuh dan berkembang.
Dari sekian banyak item kebudayaan tersebut, peniliti lebih tertarik mengkaji tradisi Perang Tembung. Karena dalam tradisi perang tembung terdapat berbabagi macam bentuk keunikan yang cukup menarik untuk dikaji lebih mendalam. Ketika kita mendengar kata perang atau peperangan, secara spontan dalam benak kita akan tergambar suasana ketegangan, penuh dengan kekerasan, kekacauan, dan perpecahan. Namun berbeda halnya dengan Perang Tembung yang peneliti angkat pada penelitian ini, dimana bukanlah perang yang dilatar belakangi adanya perpecahan atau pertikaian serta bukanlah perang yang bertujuan untuk merebut suatu bentuk kekuasaan seperti yang selama ini terkonstruk dalam pemikirannya. Di dalam perang ini merupakan suatu bentuk kegiatan yang unik, saling 
melempar dengan tembung antara peserta atau masyarakat yang ada di halaman makam serewe (tempat yang disucikan atau dikeramatkan oleh masyaraat islam yang ada di Desa Serewe) dengan peserta atau masyarakat yang ada di luar serewe.

Tradisi Perang Tembung ini dilakukan oleh masyarakat Islam yang berdomisili di Desa serewe pada waktu dan tempat yang di lakukan setelah selese lebaran topat, yaitu di makam serewe, Desa serewe, Kecamatan praya tengah, kabupaten Lombok tengah. Di dalam makam serewe ini terdapat makam datu kerajaan pejanggik.(Tempat yang di keramatkan)bagi pemeluk agama Islam Sasak.tempat ini boleh dipakai kapan saja menurut keperluan agama masing- masing, tetapi hanya sekali dalam setahun diadakan upacara kebudayaan tersebut yakni Perang Tembung itu sendiri.

Keberadaan upacara Perang Tembung ini bersifat turun-temurun dan pelaksanaannya tidak hanya diikuti oleh penduduk setempat, tetapi juga diikuti oleh orangorang yang berasal dari luar.Upacara ini biasanya dilaksanakan pada setelah selesai lebaran topat menurut penghitungan bulan ke-tujuh kalender Sasak atau sekitar bulan November - Desember Tarikh Masehi.Pada dasarnya upacara ini dilaksanakan sesudah lebaran topat.

Tradisi ini dilakukan sebagai pengungkapan kegembiraan dan rasa terima kasih kepada Yang Maha Kuasa.Dasar pemikirannya adalah untuk mengembalikan hasil tanah (berupa tembung yang terbuat dari beras atau padi) menuju asalnya. Hasil itu diyakini akan berguna sebagai pupuk untuk benih padi yang akan ditanam berikutnya.

Mencermati hal diatas, bagi peneliti sendiri aktifitas mereka secara kultural sangat menarik untuk dikaji, karena di dalam prakteknya terdapat perpaduan budaya yang selanjutnya disebut akulturasi budaya antara Islam dengan budaya lokal, sehingga dengan demikian peneliti mencoba melihatnya ke dalam ranah ilmiah dalam konteks kajian silang budaya (cross culture comparation). Selain itu, sepengetahuan peneliti sampai saat ini, belum ada referensi yang concern membahas tentang bentuk akulturasi agama dan budaya yang terjadi pada tradisi Perang Tembung ini. Begitupun dengan keberadaan dari tradisi Perang Tembung

\section{B. METODE PENELITIAN}

Tradisi pada masyarakat serewe, maka penelitian ini menggunakan pendekatan Kualitatif. Lebih lanjut mengenai pendekatan kualitatif, Lexy J. Moleong (2004) lebih jelas mendiskripsikan pendekatan kualitatif sebagai suatu bentuk pendekatan yang dilakukan dalam penelitian dengan cara terjun langsung kelapangan, dengan berhadapan langsung dengan responden guna memperoleh data yang valid. Penelitian kualitatif adalah prosedur penelitian yang menghasilkan data deskripsi berupa kata-kata, tertulis atau lisan dari orang-orang dan prilaku yang dapat di amati dari subyek itu sendiri, khususnya pada Perang Tembung itu sendiri.

Lokasi penelitian di Desa serewe kecamatan praya tengah kabupaten Lombok tengah Propinsi Nusa Tenggara Barat. Pemilihan wilayah ini didasarkan pada alasan bahwa Desa serewe merupakan satu-satunya tempat berlangsungnya acara disamping itu juga penyelenggaraannya yang unik dan menarik mendorong peneliti untuk menetapkan lokasi tersebut sebagai lokasi penelitian

Adapun subyek dalam penelitian ini adalah masyarakat (umat) umat Islam Desa seewe Kecamatan praya tengah Kabupaten Lombok Tengah Propisi NTB yang melaksanakan Perang Tembung, sedangkan yang menjadi obyek penelitiannya ialah prosesi Perang Tembung yang dilaksanakan oleh masyarakat Desa serewe teknik pengumpulan data menggunakan observasi, wawancara dan domukentasi.

\section{HASIL DAN PEMBAHASAN}

\section{Perang Tembung Sebagai Suatu Simbolisasi Kerukuran Antar Umat Beragama}

Pada dasarnya budaya atau kebudayaan suatu masyarakat merupakan hasil abstraksi manusia, yang mana manusia merupakan elemen dan bagian dari suatu masyarakat. Tampa adanya manusia, maka tidak akan pula terbentuk suatu kebudayaan yang pada gilirannya tumbuh dan berkembang dalam suatu 
masyarakat itu sendiri.

Budaya seperti yang diungkapkan oleh Koentjoro Ningrat (2001) dalam bukunya "Pengantar Antropologi I" yang menyatakan bahawa budaya pada hakikatnya merupakan hasil perenungan mendalam dari masing-masing individu manusia yang berupa hasil karya, cipta, karsa, rasa yang kemudian tumbuh dan berkembang dalam sebuah masyarakat dengan adanya sebentuk konsensus atau kesepahaman dan kesepakatan dari keseluruhan anggota masyarakat untuk menjadikannya sebagai pedoman atau pegangan dalam hidup dan kehidupan mereka yang didukung oleh keyakinan dan rasa saling mempercayai antar satu sama lainnya sehingga kebudayaan itu terus berkembang dan tumbuh di tengah- tengah masyarakat tersebut. Lebih lanjut Parsons (1937-1966) menyatakan bahwa inti setiap masyarakat adalah jalinan makna, kepercayaan dan nilai suatu masyarakat dapat membentuk struktur cara-cara dasar mereka dalam mengorganisasikan kehidupan sosialnya.

Tradisi sebagai komponen dari kebudayaan pun juga akan tetap tumbuh dan berkembang dalam suatu masyarakat manakala masyarakatnya mampu melestarikannya dengan baik. Antara pola hidup suatu masyarakat memiliki hubungan kausalitas yang tinggi. Pada suatu sisi tertentu kebudayaan atau tradisi suatu masyarakat akan berpengaruh besar terhadap bagaimana bentuk pola hidup yang dijalani oleh masyarakat tersebut, dan disisi lain justru sebaliknya pola hidup yang berkembang ditengah masyarakat tidak sedikit pula akan berpengaruh besar terhadap keberadaan suatu bentuk kebudayaan dan tradisi telah lama mereka jadikan pijakan dalam hidup. Muchtar Lubis (1985 : 77) dalam bukunya : “ Transformasi Budaya Untuk Masa Depan “ menyatakan bahwa : " Budaya adalah suatu yang tumbuh, berkembang dan berubah dalam sebuah proses yang terus menerus berkesinambungan, ia tidak tumbuh sendiri dan perkembangan nilai hasrat, harapan, agama, seni, tingkah laku, ilmu teknologi dan lain-lain, yang membuat masyarakat hidup dan berkembang, tetapi budaya dapat juga mati dan hancur, kering dan hampa. Jika bidang-bidang kehidupan masyarakat yang lain berkembang buruk dan mengakibatkan keruntuhan sendi-sendi masyarakat.

Demikian pula halnya dengan Tradisi Perang Tembung sebagaimana yang penliti bicarakan pada hasil penlitian ini.Seperti yang telah diungkapkan sebelumnya, dimana Tradisi Perang Tembung merupakan salah satu hasil perenungan mendalam dari masyarakat suku Sasak khususnya yang ada di Desa Serewe itu sendiri.Pada hakikatnya tradisi ini memiliki niali historis yang cukup vital dan mendalam dalam masyarakat Sasak di Desa Serewe.

Esensi uatama yang terkandung dalam TradisiPerang Tembung yang dimaksudkan ini adalah sebentuk ciri khas sebagai jati diri masyarakat Sasak khususnya dalam menjalani kehidpan beragama. Nilai vital yang terkandung di dalam tradisi ini adalah kerukunan antar umat beragama yakni antara agama Islam Hal itu terlihat dari adanya sebentuk proses pembauran atau akulturasi antara umat beragama yang sama.

Gambaran (simbolisasi) mengenai bentuk kerukunan antar umat beragama islam yang ada di Desa Serewe, meskipun terjadi saling adu lempar Tembung antara mereka namun tidak ada rasa dendam yang tampak, berbeda halnya manakala kita lihat orang-orang tawuran antar ampung atau antar kelompok.

Dalam pandangan umum peneliti, pada akulturasi atau perpaduan antara satu agama yakni agama Islam yang ada pada tradisi Perang Tembung tersebut memiliki makna sebagai simboliasi tersendiri antar masing-masing agama dengan memadukan karakteristiknya. Antara agama Islam masing-masing memberikan kontribusi tersendiri dalam setiap rangkain prosesi acara Perang Tembung tersebut.

Jika kita telusuri kembali berdasarkan konteks historis yang terkandung dalam tradisi Perang Tembung ini, yang mana tradisi tersebut lahir sebagai simboliasi atau perwujudan kebaktian kepada Tuhan Yang Maha Esa yang sama- sama mereka yakini keesaanNya sehingga terbentuk kerukunan antar umat beragama yang sama tersebut. 
a) Upacara pujawali

Dalam pelaksanaan Upacara Pujawali ini terdapat berbagai persiapan yang dilakukan, yang juga masuk sebagian dari upacara ini secara ritual, persiapan upacara ini sudah dimulai beberapa hari sebelumnya. Sedangkan untuk memeriahkan dan menyemarakan upacara ini beberapa hari sebelum dan sesudahnya diadakan berbagai macam hiburan dan kesenian untuk rakyat. Hal demikian ini menunjukkan bahwasanya dalam keadaan senang maupun susah setiap elemen masyarakat harus tetap berada dalam kebersamaan saling merangkul membentuk suatu keutuhan yang harmonis.

Disamping itu pula, pujawali dimaksudkan sebagai kebaktian dan pengabdian terhadap Tuhan Yang Maha Esa dengan saling mendoakan satu sama lainnya. Dalam suasana pujawali ini tercermin bahwasanya antara masyarakat yang satu dengan yang lainnya tidak ada dinding pemisah yang harus membedakan antara mereka sehingga tetap berada pada satu tempat yang sama di bawah naungan rahmat Tuhan.

b) Arak-arakan Kebon Odek

Sebelum Perang Tembung dimulai, Kebon Odek (sejenis arak-arakan) dikeluarkan dari kemaliq/ tempat pelaksanaan perang tersebut yang bertujuan untuk menjemput pesajik (sesajen) kemudian dikelilingi sebanyak 3 kali di kemaliq lalu di upacarakan.Kebon Odek ini di arak oleh orang-orang yang ditunjuk oleh masing-masing kubu yakni kubu Islam.Kondisi ini memberikan gambaran kepada kita bahwasanya Kebon Odek (arak-arakan) merupakan sebentuk kesepakatan yang mereka bangun bersama yang kemudian mereka usung dan mereka pegang teguh sebagai lambang kerukunan yang selalu sejalan. Hal itu tidak hanya terputus sampai di situ, namun juga kondisi tersebut harus senantiasa tumbuh dan berkembang dalam kehidupan mereka sehari-hari.

c) Pesajik (Sesaji)

Pesaji merupakan sebentuk sesaji yang digunakan sebagai persembahan dalam upacara pujawali.Hal itu menunjukkan adanya sebentuk kesatuan dalam pola fikir masyarakat Desa Serewe mengenai kewajiban terhadap Tuhan Yang Maha Esa untuk berkorban dan selalu memberikan hal-hal yang terbaik kepada sang pencipta. Manusia sebagai mahluk dan hamba yang baik adalah mereka yang mampu berbakti terhadap tuhannya, dan sesaji tersebut merupakan wujud kebaktian mereka (masyarakat Desa Serewe).

\section{Perang Tembung Merangkul Kultur dan Kepercayaan Masyarakat Serewe}

Nampkanya menjaga keutuhan dan kelangsungan suatu bentuk budaya atau tradisi memang teramat sulit jika kita benturkan dengan globalisasi dan modernisasi yang tengah berkembang dewasa ini. Dimanapun kita saksikan saat ini, posisi kebudayaan tradisional seolaholah terus tertekan dan terpojokkan keberadaannya. Seiring laju perkembangan dan perubahan pola hidup manusia yang selama ini diklaim terus mengalami perubahan dalam konteks perkembangan menuju arah yang lebih baik.Keyakinan-keyakinan demikian tentunya tumbuh dan berkembang di tengah-tengah masyarakat modern yang identik dengan masyarakat perkotaan (gesellschaf).

Pada kondisi tertentu, budaya tradisional bagi masyarakat modern justru dianggap sebagai sesuatu yang menghambat terjadinya proses perkembangan karena sifatnya yang mengikat dan stagnan. Untuk itu, demi mencapai suatu kearah yang membawa manusia kepada kemajuan dan perkembangan, maka pada tradisi atau kebudayaan tradsional memang seharusnya dilakukan sebentuk perubahan yang revolusioner seperti yang diungkapkan oleh Comte (1830-1842) dengan konsep positivisnya yang memandang perubahan hidup manusia dan segala unsur yang ada di dalamnya terutama kebudayaan suatu suku bangsa di dunia ini berjalan secara liner (lurus dan meningkat ) atau dengan kata lain bahwasanya pola kehidupan manusia terus mengalami perubahan kearah yang selaras. Akan tetapi konsep tersebut cendernung dibantah oleh Pitirim Sorokin (1889) yang menyatakan bahwasanya konsep kehidupan manusia dan kebudayan yang berkembang di tengah kehidupan mereka adalah berjalan dalam alur siklus tertentu, yakni pada suatu kondisi tertentu manusia akan mencapai titik jenuh (klimaks) sehingga mereka akan kembali pada konsep awal kehidupan 
mereka, untuk itu kehidupan manusia diumpamakan selalu berputar dalam lingkaran setan.

Peneliti sependapat dengan apa yang diutarakan oleh kedua tokoh tersebut, karena memang pada kondisi tertentu kebudayaan suatu suku bangsa memang akan megalami sebentuk evolusi dan revolusi yang merombak apa yang memang telah menjadi pegangan hidup mereka selama bertahun-tahun dan berabad-abad hingga tidak sedikit dari kebudayaan dan tradisi yang tidak mampu bertahan dengan kondisi yang ada dan akhirnya lenyap tanpa meninggalkan jejak karena dianggap tidak sejalan lagi dengan kondisi pola hidup yang berkembang. Namun pada sisi yang bersimpangan dari itu, suatu bentuk tradisi dan kebudayaan tardisional akan mampu bertahan dan berkembang melalui proses penyesuaian diri dengan pola yang tengah berkembang meskipun pada situasi tertentu pula tradisi dan kebudayaan tersebut sedikit melenceng dari keadaan semestinya, apalagi jika dibenturkan dengan globalisasi sebagai hasil dari modernisasi.

Layaknya kebudayaan dan tradisi lainnya, jika kita benturkan dengan modernisasi tidak sedikit budaya dan tradisi yang telah mulai ditinggalkan oleh pemiliknya. Tradisi Perang Tembung pun demikian juga, lambat laun akan mengalami sebentuk pergeseran dan tidak menutup kemungkinan untuk musnah. Namun kondisi tersebut sedikit tidak mampu dibendung dan diminimalisir oleh masyarakat Desa Serewe, hal itu terbukti dengan masih berkembangnya tradisi Perang Tembung yang hidup di tengah-tengah modernisasi serta keberagaman kultur dan kepercayaan yang sama.

Perang Tembung itu sendiri terbentuk dari akulturasi budaya dan keyakinan yang sama tersebut dan termanifestasi dalam bentuk kerukunan antar umat beragama. Pada suatu tempat yang sama yakni Desa Serewe, satu agama dan satu tetap keyakinan hidup berdampingan dan beriringan serta terangkul dalam satu bentuk tradisi yang lahir sebagai bentuk kesepahaman dan kesepakatan antar kedua belah pihak, sehingga menjadi panutan dan filosofi hidup mereka sehari- hari. Kesepahaman dan kesepakatan yang dimaksudkan di sini bukan berarti masing-masing agama saling masuk memasuki untuk satu sama mencampuri dan mengintervensi permasalahan peribadatan masingmasing agama. Interaksi di antara kesatu pihak tersebut akan tetap berjalan lancar tanpa gangguan apa pun manakala simbol yang dikeluarkan oleh masing-masing pihak dimaknakan bersama untuk membentuk suatu kesepakatan yang searah sehingga semua pihak mampu mengartikannya dengan baik.

tradisi Perang Tembung mampu bertahan hingga sekarang ini adalah karena tradisi tersebut menyentuh lini keyakinan. Apabila sesuatu telah menyentuh perihal keyakinan yang telah tertanam kuat di dalam hati manusia maka akan sangat sulit untuk dilupakan karena keyakinan itu sendiri muncul dari salah satu kebutuhan dasar manusia, serta sebagai suatu hasil dari keajekan yang telah berlangsung lama. Seperti yang diungkapkan oleh David Mc. Cleland yang melihat manusia meyakini dan melakukan sesuatu berdasarkan need for achievmennya. Keyakinan atau need for achievmen tersebut yang senantiasa selalu dipupuk oleh masyarakat Desa Serewe melalui proses institusionalisasi, sehingga mampu meredam berbagai bentuk konflik antar keyakinan yang ada. Institusionalisasi yang dimaksudkan di sini tidak terbatas pada proses pelembagaan yang sifatnya fisik, namun lebih dari itu. Institusionalisasi yang dimaksudkan adalah adanya proses penyatuan persepsi yang berlangsung secara kontinyu.

bahawasanya pada diri masyarakat Desa Serewe tertanam keyakinan yang cukup mengakar dan mendarah daging sehingga seolah mereka memiliki sugesti tersendiri untuk tetap melaksanakan dan mempertahankan tradisi perang tembung tersebut. Namun meskipun demikian bukan berarti tidak ada sebentuk ancaman yang cukup berarti karena tidak selamanya interaksi berjalan mulus. Ada pihak-pihak tertentu yang menggunakan simbol yang tidak signifikansimbol yang tidak bermakna bagi pihak lain.

\section{SIMPULAN DAN SARAN}

\section{Simpulan}

a) Perang Tembung pada dasarnya muncul sebagai simboliasi atau perwujudan kebaktian kepada Tuahan Yang Maha Esa yang sama-sama 
mereka (masyarakat Islam) yakini keesaannya sehingga terbentuk kerukunan antar umat beragama yang sama tersebut. Dengan demikian mereka bersama-sama melaksanakan permohonan kemakmuran agar mendapatkan rezeki yang berlimpah khususnya dalam hal hasil panen seperti halnya hujan Tembung yang mereka lempar pada waktu pelaksanaan Perang Tembung tersebut. Selanjutrnya Perang Tembung juga diyakini sebagai anugrah sesaji yang dianggap mengandung (air kehidupan) yang diperebutkan oleh masyarakat yang percaya, kemudian ditaburkan diatas tanah pertanian maupun di tempat yang di jadikan sumber penghasilan. Disamping itu sebagian warga juga menyebar Tembung sisa Perang Tembung ke sebagian air agar hasil panennya bisa maksimal.

b) Perang Tembung itu sendiri terbentuk dari akulturasi agama dan keyakinan yang sama tersebut dan termanifestasi dalam bentuk kerukunan antar umat beragama. Pada suatu tempat yang sama yakni Desa Serewe, agama dan keyakinan hidup berdampingan dan beriringan serta terangkul dalam satu bentuk tradisi yang lahir sebagai bentuk kesepahaman dan kesepakatan antar kedua belah pihak, sehingga menjadi panutan dan filosofi hidup mereka sehari-hari. Kesepahaman dan kesepakatan yang dimaksudkan di sini bukan berarti masingmsing agama saling masuk memasuki untuk satu sama mencampuri dan mengintervensi permasalahan peribadatan masing- masing agama. Akan tetapi pembauran (akulturasi) yang dimaksudkan di sini tidak hanya akulturasi yang terbatas pada dimensi ruang dan waktu. Namun lebih dari itu, pembauran ini menyentuh lini-lini keyakinan dan pemikiran masyarakat Desa Serewe yang termanivestasi dalam bentuk tradisi Perang Tembung. Hal tersebut menjadi suatu simboliasi yang nyata mengenai pola hidup dan kondisi kehidupan masyarakat yang berkembang di Desa Serewe.

\section{Saran}

a) Peneliti sadari bahwasanya dalam proses dan hasil dari penelitian ini tidak sesempurna dan seoptimal yang kita harapkan bersama karena adanya beberapa hambatan uyang cukup berarti. Untuk itu, demi optimalisasi dan keterlangsungan penelitian yang ada, peneliti sendiri berharap:

b) Pemerintah daerah setempat (Pemerintah Kabupaten) sekiranya memberikan sebentuk solusi yang baik dalam hal pengadaan bahan refrensi, baik yang berupa buku, kliping dan dokumentasi lain yang bisa dijadikan sebagai bahan refrensi dalam bidang kebudayaan yang secara khusus mengkaji masalah Perang Tembung.

c) Pemerintah Desa dan Kecamatan senantiasa harus melestarikan tradisi Perang Tembung, karena bagaimanapun juga tradisi ini merupakan warisan leluhur yang cukup unik dan memiliki nilai budaya yang cukup tinggi. Untuk itu, harus ada sebentuk regenerasi yang dilakukan oleh masyarakat setempat khususnya kepada generasi muda agar tertanam rasa memiliki terhadap tradisi Perang Tembung tersebut.

\section{DAFTAR RUJUKAN}

Abdusyakur, Ahmad. 2006. Islam Dan Kebudayaan: Akulturasi Nilai-Nilai Islam Dalam Budaya Sasak, Yogyakarta: Abad Press.

Abdurrahman Dudung.2007.Metodelogi Penelitian Sejarah. Jogjakarta:Ar-Ruzz Media

Ali, M. Sayuthi, 2002. Metodologi Penelitian Agama Pendekatan Teori Dan Praktek. Jakarta: PT. Raja Grafindo Persada.

Arikunto, Suharsimi, 2002. Prosedur Penelitian Suatu Pendekatan Praktek. Jakarta: PT. Rineka Cipta.

Azhar, Lalu Muhammad, dkk. 1996. Pengaruh Budaya Asing Terhadap Kehidupan Sosial Budaya Sasak di Daerah Nusa Tenggara Barat. Mataram, Faforit Offset.

Bugin Burhan.2007.Penelitian Kualitatif. Jakarta:Kencana

Berry, David, 2002. Pokok-Pokok Fikiran Dalam Sosiologi. trj. Paulus Wirutomo. Jakarta: PT. Raja Grafindo Persada.

Budiwanti, Erni. 2000. Islam Sasak (Wetu Telu Versus Waktu Lima ). Yogyakarta: LKiS.

Durkheim, Emile. Sejarah Agama. trj. Paulus Wirutomo. Jakarta: PT. Raja Grafindo Persada. 2002. 
Hakim, Abdul, Metodologi Kualitatif Dan kuantitatif, Fakultas Ilmu Administrasi, Universitas Bariwijaya.

Jalaluddin, Rakhnmat, Drs, M.Si dan Dr. Deddy Mulyana, M.A, 2005, komunikasi antar budaya, Bandung, PT. Remaja Rosdakarya

Jhonson, Deyle Paul. 1990. Teori Sosiologi Klasik dan Modern Jilid T. Universitas of South Florida.. 1990. Teori Sosiologi Klasik dan Modern Jilid II.Universitas of South Florida.

Kuntowijoyo.2003. Metodologi Sejarah.Yogyakarta:Tina Wacana Jogja. Koentjaraningrat. 2009. Pengantar Ilmu Antropologi. Jakarta: PT. Rineka Cipta

Koentjaraningrat.2005. Metode-Metode Penelitian Masyarakat. Jakarta: PT.Gramedia

Koenjtaraningrat, 2001. Pengantar Antropologi 1. Jakarta: PT. Rineka Cipta.

Mundzirin Yusuf, 2005. dkk, Islam dan Budaya Lokal (Yogyakarta: Pokja Akademik UIN)

Moleong, J. Lexy, 2004, Metodologi Penelitian Kualitatif, Bandung: PT. Remaja Rosda Karya .

Rendra, 2005. Mempertimbangkan Tradisi. Jakarta: PT. Gramedia.

Soekanto, Soerjono. 2003. Sosiologi suatu pengantar. Jakarta: Grafindo persada. Soeloeman, M.

Munandar, 2007, Ilmu Budaya Dasar. Suatu Pengantar, Bandung: Rafika Aditam

Sirade, Umar. 1998. Perubahan Nilai Upacara Tradisional Pada Masyarakat Pendukung di Daerah NTB: Dapertemen Pendidikan dan Kebudayaan RI. Tim Penyusun. 2011. RPJMDes. DESA SEREWE2011-2015. Perangkat Kecamatan Praya Tengah 